\title{
Tourism citations in other disciplines
}

Cassandra Wardle, Ralf Buckley*

Griffith University, Australia

*Corresponding author. Address: International Centre for Ecotourism Research, Griffith University, Gold Coast, QLD 4222,

Australia. Tel.: +61 7 55528675; fax: +61 755528895 .

E-mail address: r.buckley@griffith.edu.au

Tourism publication and citation patterns have been analysed repeatedly: most recently, by Hall (2011), Benckendorff and Zehrer (2013), Fennell (2013), and Xin, Tribe, and Chambers (2013). Initially there were few researchers or journals, and ideas and information were largely imported from other disciplines. This has continued, but as tourism research expanded, it also became increasingly self-referential. Here we examine whether it has entered a third phase, with outward citations in other academic disciplines: a key criterion for a mature field of study. For comparison, economics research examines how humans allocate resources, and is cited across many other disciplines. Tourism research examines how humans move around, which a priori seems equally fundamental. Here, therefore, we test how widely tourism research is cited in non-tourism journals. All searches were conducted during 2012 and 2013.

We used a rationally efficient search strategy to answer this question robustly and reliably. It might theoretically be possible to search the world's entire electronic literature for all citations of all articles in all tourism journals, but this would be very inefficient. Our strategy involved two steps. The first step used an iterative approach to identify the tourism journals most often cited in other disciplines. Part of this iteration involved the identification of nontourism disciplines most commonly cross-cited cited with tourism. This step is a precaution, required since the impact factors of tourism journals are derived largely from citations of articles in other tourism journals. Thus, IFs of tourism journals may not accurately identify the journals cited most often in non-tourism journals. This step does not generate final data. It is simply to ensure that the second step captures the dense part of the dataset, the fat body rather than the long tail, because that determines the reliability of the overall result. In the second step, we compiled and analysed all citations in non-tourism journals, for all articles published in highly-cited tourism journals. This is the step which generated our primary data. 
To identify tourism journals most often cited in non-tourism journals, we used five substeps. First, we scanned $\sim 400$ articles from the three top-IF tourism journals to identify non-tourism disciplines cited frequently within tourism journals. We searched first for broad-scale basic disciplines, and found five: psychology, sociology, biology, geography and economics, save that biology was represented only by the subfield ecology. We then searched for more applied fields such as management, marketing and policy. We found that the development studies literature is heavily cited, and added this one applied field only. Next, for each of these six fields, we identified the five specialist journals with highest impact factors, 30 journals in all. We then selected two of each five, a random $40 \%$ sample, and searched retrospectively to identify all citations using the word tourism or related terms. Finally, we used these results to rank tourism journals on frequency of citation in the journals of nontourism disciplines. The parameters used to narrow the iterative search, namely 6 top fields, 5 top journals, and a $40 \%$ subsample, are not critical, for reasons outlined earlier. This step is only to identify key tourism journals.

We found seven tourism journals which are all at least three times more heavily cited in nontourism journals than all other tourism journals. These are: Annals of Tourism Research (192 articles cited), Tourism Management (72), Tourism Geographies (35), Journal of Travel Research (27), Tourist Studies (17), Journal of Sustainable Tourism (14), and Current Issues in Tourism (12). That is, the list includes well-known tourism journals, but not in the order of impact factors. The high number of citations for Tourism Geographies is of particular note. For all remaining tourism journals we found only 3,2, 1 or 0 non-tourism citations each. The top seven listed above thus contribute $>85 \%$ of the total.

In the second step, we used Google Scholar® to search for citations in non-tourism journals from the top seven tourism journals. For triangulation, we also examined the entire electronically-searchable histories, since the journals were established, for the 30 non-tourism journals identified above. In each case, we searched with all applicable citation styles and abbreviations. Google Scholar® proved more comprehensive. Only one non-tourism journal (Global Environmental Change) commenced publication later than the tourism journals, so this does not produce bias. We obtained a database of 402 articles from the top seven tourism journals, cited in 109 articles in non-tourism journals. 
We found that some tourism articles are cited in multiple non-tourism publications: up to eight, for Britton (1982). Over $80 \%$ of the articles in non-tourism journals, that cite from tourism journals, cite <5 individual tourism articles. Cohen (1984), Squire (1994) and Sinclair (1998), however, cite 40 each; and Dieke (1993), Gibson (2008) and Waitt, Markwell, and Gorman-Murray (2008) each cite 15-25. Publication dates for cited tourism articles commence from 1974. The mean lag from publication to citation of individual tourism articles is 6.6 years, and the mode is three years. The number of individual tourism articles cited in non-tourism journals has remained steady at around 15 per year, with high variability but no significant trend $(\mathrm{p}>0.05)$ over the past 33 years. The number of citing articles in non-tourism journals, however, has increased significantly $(\mathrm{p}<0.001)$, rising from zero in the early 1980s to a mean of around eight per year in 2013 (Fig. 1).

Tourism articles were cited in non-tourism journals with both higher and lower impact factors. They were also cited in four journals with higher IF than any tourism journal: Economic Geography (4.0), American Sociological Review (4.4), Global Environmental Change (6.9), and Ecology Letters (IF 17.6). This last (Balmford \& Bond, 2005) is the highest-ranked article citing tourism journals. There are three small items referring to tourism in the top-ranked Nature (IF 37) (Buckley, 2010, 2013; Buckley \& Pabla, 2012), and one article that mentions tourism in the second-ranked journal Science (IF 32) (Bateman et al., 2013), but none of these cite tourism journals.

Over $70 \%$ of the articles in non-tourism journals were written specifically about tourism, e.g. reviewing tourism from their own disciplinary perspective. Many of these authors publish in both tourism and non-tourism journals, and some of the citations are their own. Examples include: Becken, Campbell, Cohen, Cukier, Dieke, Duval, Gössling, Manuel-Navarrete, Markwell, Monsen, Poon, Sinclair, Tol, Torres, and Wall. Only 31 articles are not specifically about tourism. These cite few tourism articles, and only two of their 50 authors publish regularly in tourism journals. All but three of these articles were published since 2005, and 11 since 2010.

The number of citations of tourism research in non-tourism disciplines is thus still very small compared to the tens of thousands of internal citations within tourism research. Fig. 1 provides a first indication, however, that tourism research is achieving recognition within other academic disciplines. We may indeed be entering a third phase of tourism research. 
Authors such as those listed above, who publish across disciplines, seem to have particular influence in this process. For tourism research to receive greater recognition outside its own walls, perhaps top-ranked tourism journals should now give greater weight, in their editorial processes, to the relevance of articles to disciplines beyond tourism; and future analyses of ideas and influence in tourism research should include non-tourism journals as well as the top-tier tourism journals routinely considered to date. 


\section{References}

Balmford, A., \& Bond, W. (2005). Trends in the state of nature and their implications for human well-being. Ecology Letters, 8, 1218-1223.

Bateman, I., Harwood, A., Mace, G., Watson, R., Abson, D., et al. (2013). Bringing ecosystem services into economic decisionmaking: Land use in the United Kingdom. Science, 341, 45-50.

Benckendorff, P., \& Zehrer, A. (2013). A network analysis of tourism research. Annals of Tourism Research, 43, 121-149.

Britton, S. G. (1982). The political economy of tourism in the third world. Annals of Tourism Research, 9, 331-358.

Buckley, R. C. (2010). Safaris can help conservation. Nature, 467, 1047.

Buckley, R. C. (2013). Three reasons for eco-label failure. Nature, 500, 151.

Buckley, R. C., \& Pabla, H. S. (2012). Tourism ban won’t help Indian tigers. Nature, 489, 33.

Cohen, E. (1984). The sociology of tourism: Approaches, issues and findings. Annual Review of Sociology, 10, 373-392.

Dawson, J., \& Scott, D. (2013). Managing for climate change in the alpine ski sector. Tourism Management, 35, 244-254.

Dieke, P. (1993). Tourism in the Gambia: Some issues in development policy. World Development, 21, 277-289.

Fennell, D. (2013). The ethics of excellence in tourism research. Journal of Travel Research, $52,417-425$.

Gibson, C. (2008). Locating geographies of tourism. Progress in Human Geography, 14, $372-390$. 
Hall, C. M. (2011). Publish and perish? Bibliometric analysis, journal ranking and the assessment of research quality in tourism. Tourism Management, 32, 16-27.

Morello, L. (2014). Winter Olympics: Downhill forecast. Nature, 506, 21-22.

Sinclair, M. (1998). Tourism and economic development: A survey. Journal of Development Studies, 34, 1-51.

Squire, S. (1994). Accounting for cultural meanings: The interface between geography and tourism studies re-examined. Progress in Human Geography, 18, 1-16.

Waitt, G., Markwell, K., \& Gorman-Murray, A. (2008). Challenging heteronormativity in tourism studies: Locating progress. Progress in Human Geography, 32, 781-800.

Xin, S., Tribe, J., \& Chambers, D. (2013). Conceptual research in tourism. Annals of Tourism Research, 41, 66-88. 
Fig. 1. Numbers of non-tourism articles citing articles from most-cited tourism journals, last 3

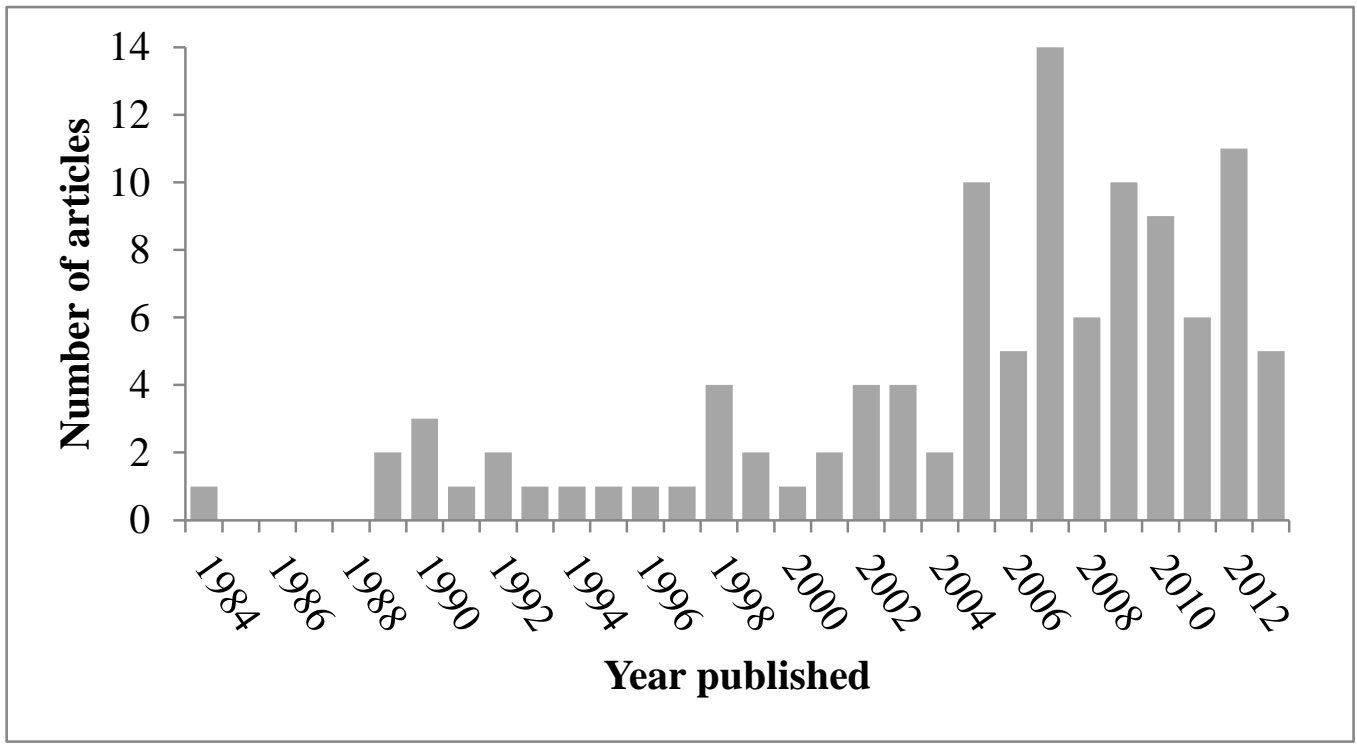

decades. 